\title{
Pharmacological Investigation on Ethanol Extract of Scindapsus hederaceus Miq.
}

\author{
Md. Mazharul Islam", Mohammed Ibrahim", Mohiminul Adib², Syed Mohammed Tareq", \\ Mohammad Rashedul Haque ${ }^{2}$ and Mohammad A. Rashid ${ }^{2}$
}

\author{
${ }^{1}$ Department of Pharmacy, Southern University Bangladesh, Mehedibag Road, Chittagong-4000, Bangladesh \\ ${ }^{2}$ Phytochemical Research Laboratory, Department of Pharmaceutical Chemistry, University of Dhaka, \\ Dhaka-1000, Bangladesh
}

\author{
Received: January 01, 2017; Accepted: January 15, 2017; Published (Web): March 19, 2017
}

\begin{abstract}
The present study was conducted to evaluate the antipyretic, anti-inflammatory and membrane stabilizing, antioxidant, thrombolytic, anti-diarrheal activities of Scindapsu shederaceus belonging to the Araceae family. In antipyretic test, temperature reduced from $101.53^{\circ} \mathrm{F}$ to $99.86^{\circ} \mathrm{F}(\mathrm{p}<0.05), 99.20^{\circ} \mathrm{F}(\mathrm{p}<0.05)$ and $99.06^{\circ} \mathrm{F}$ $(\mathrm{p}<0.05)$ in $1^{\text {st }}, 2^{\text {nd }}$ and $3^{\text {rd }}$ hour, respectively and caused maximum reduction of temperature in $1^{\text {st }}$ hour. In the hot plate method, the extract increased the reaction time of heat sensation significantly to 14.32 seconds. In in vitro anti-inflammatory test, the extract significantly inhibited protein denaturation by $85.17 \%$ at $500 \mu \mathrm{g} / \mathrm{ml}$, $71.72 \%$ at $250 \mu \mathrm{g} / \mathrm{ml}$ and by $66.55 \%$ at $125 \mu \mathrm{g} / \mathrm{ml}$. It also inhibited the hypotonic solution-induced haemolysis by $73.19 \%, 49.69 \%$ and $29.15 \%$ at same concentration in membrane stabilizing assay. In DPPH inhibition assay the extract showed maximum \% inhibition of $65.5 \%$ at $100 \mu \mathrm{g} / \mathrm{ml}$. In the assay of thrombolytic activity, the extract showed thrombolytic activity of $14.39 \%$. Amylase inhibitory activity was found to be $22.38 \%$ at a concentration $100 \mu \mathrm{g} / \mathrm{ml}$. In case of antidiarrheal investigation, the extract reveled total inhibition of defection by $35.30 \%$.
\end{abstract}

Key words: Scindapsus hederaceus Miq., anti-inflammatory, membrane stabilizing, thrombolytic, antidiarrheal, antipyretic.

\section{Introduction}

Science has isolated the medicinal properties of a large number of botanicals, and their healing components have been extracted and analyzed. Many plant components are now synthesized in large laboratories for use in pharmaceutical preparations (LaValle et al., 1999). A medicinal plant is any plant which, in one or more of its organ, contains substance that can be used for therapeutic purpose or which is a precursor for synthesis of useful drugs. This definition of Medicinal plant has been formulated by World Health Organization (WHO, 2002). It has now been established that the plants which naturally synthesis and accumulate some secondary metabolites like alkaloids, glycosides, tannins, volatile oils and contain minerals and vitamins, possess medicinal properties (Sofowara,
1982). WHO estimates that herbal medicine is still the mainstay of about $75-80 \%$ of the world population, mainly in the developing countries, for primary health care because of better cultural acceptability, better compatibility with the human body and lesser sideeffects (Rao et al., 2011).The use of natural substance, particularly plants, to control diseases is centuries-old practice that has led to the discovery of more than half of all "Modern" pharmaceuticals. Historically pharmacological screening of compounds of natural or synthetic origin has been the source of innumerable therapeutic agents (Mahesh, 2008). S. hederaceus a member of the family Araceae. It is a large climbing herb where the stem is slender, with clasping roots, fruit is a red in color of berry, seed is subreniform, compressed and thick, and the leaves are arranged

Correspondence to: Mohammad A. Rashid; Tel.: +880-2-9661900; extn-8137; E-mail: rashidma@du.ac.bd 
alternate, simple and entire, elliptical-lance-shaped (De Padua and Bunyapraphatsara, 2003). The fruit is credited with stimulant, diaphoretic, aphrodisiac, carminative and anthelmintic properties, and is used to stop diarrhea and as an expectorant to treat asthma. It also has antiprotozoal activity and is applied externally to treat rheumatism.

\section{Materials and Methods}

Plant materials and extraction: Fresh plants were collected from the hill tracts area of Ramu, Cox'sbazar, Chittagong, in the month of February where taxonomical identification of this plant was made by the experts of Bangladesh Forest Research Institute (BFRI) Herbarium, Chittagong. After removing the extraneous, undesired substances from the plant material by hands, the soil was removed by sieving and the leaves were then subjected for shade dry at temperature not exceeding $50^{\circ} \mathrm{C}$ (Evans, 2002). After grinding, the powder was stored in airtight containers until extraction was commenced. For hot extraction, about $90 \mathrm{gm}$ powder of the plant was subjected with $700 \mathrm{ml}$ of ethanol (99\%) in a Soxhlet apparatus (Bhaland Bhal, 1992).

Anti-inflammatory activity: The reaction mixture consisted of $3 \mathrm{ml}$ of 5\% egg albumin (from fresh hen's egg) solution prepared and $3 \mathrm{ml}$ of varying concentrations of the test extract so that final concentrations become 125, 250 and $500 \mu \mathrm{g} / \mathrm{ml}$, respectively. Similar volume of ethanol served as control. The $\mathrm{pH}(5.6 \pm 0.2)$ of the all reaction mixtures was adjusted by $0.1 \mathrm{~N} \mathrm{HCl}$. Then the mixtures were incubated at $37 \pm 2{ }^{\circ} \mathrm{C}$ in a BOD incubator (Labline Technologies) for 15 minutes and then heated at $57^{\circ} \mathrm{C}$ for $20 \mathrm{~min}$. After cooling, their absorbance was measured at $660 \mathrm{~nm}$ by using vehicle as blank. Acetyl salicylic acid (Aspirin) at the same concentration range was used as reference drug and treated similarly for determination of absorbance (Sarafet al., 1999).

Membrane stabilizing activity: The membrane stabilizing activity of the extractives was evaluated by the inhibition of heat- and hypotonic solution inducedhaemolysis of human erythrocytes following the method developed by Omaleet al. (Omaleand Okafor, 2008).
$D P P H$ free radical scavenging activity: Following the method developed by Brand-Williams (Berset et al., 1995), the antioxidant activity of the test samples was assessed by evaluating the scavenging activities of the stable 1,1-diphenyl-2-picrylhydrazyl (DPPH) free radical by using synthetic antioxidants, butylated hydroxy toluene (BHT) and ascorbic acid as reference standards.

Thrombolytic activity: The method developed by Prasad and Harbertson (Daginawalaet al., 2007) was used to determine the thrombolytic activity by using streptokinase (SK) as positive control. Aliquots (5 ml) of venous blood were drawn from healthy volunteers that were distributed in five different pre-weighed sterile alpin tubes (500 $\mu \mathrm{L} /$ tube) and incubated at $37^{\circ} \mathrm{C}$ for 45 minutes. After clot formation, the serum was completely removed without disturbing the clot and each tube having clot was again weighed thereafter to determine the clot weight.

Antidiarrheal activity: Antidiarrheal activity was assessed by the castor oil-induced diarrhea in mice (Shoba and Thomas, 2001).

Antipyretic activity: This study was conducted by slightly modifying the method described by Adams (Nicholson et al., 1968). The experimental mice which showed at least an increase in rectal temperature to at least $34.27^{\circ} \mathrm{F}, 18 \mathrm{hrs}$ after Brewer's yeast injection. The crude methanol extract (BLME) exhibited a significant $(p=0.05)$ lowering of mice's body temperature which was elevated by the administration of yeast. These effects were pronounced at the $2^{\text {nd }}$ and $3^{\text {rd }}$ hour post-treatment with extract. The antipyretic effects of the extract were comparable to that of the standard paracetamol.

\section{Results and Discussion}

The effect of ethanol extract of $S$. hederaceus on mice is presented in table 1 . In this test, the extract at a dose of $500 \mathrm{mg} / \mathrm{kg}$ b.w significantly attenuated hyperthermia in mice up to 3 hours. Throughout the experiment, the extract reduced temperature from $101.53^{\circ} \mathrm{F}$ to $99.86^{\circ} \mathrm{F}, 99.20^{\circ} \mathrm{F}$ and $99.06^{\circ} \mathrm{F}$ in $1^{\text {st }}, 2^{\text {nd }}$ and $3^{\text {rd }}$ hour respectively. The antipyretic activity of the extract was significant $(\mathrm{p}<0.05)$ compared to the control. 
In the study of in vitro anti-inflammatory effect, $S$. hederaceus was evaluated against denaturation of egg albumin. The results are summarized in table 2. Acetyl salicylic acid was used as reference drug in the experiment at the concentration range (500-125 $\mu \mathrm{g} / \mathrm{ml})$ which exhibited concentration dependent inhibition of protein denaturation. The present experiment exhibited a concentration dependent inhibition of protein denaturation by $85.17 \%, 71.72 \%$ and $66.55 \%$ with $S$. hederaceus throughout the typical concentration range of $500 \mu \mathrm{g} / \mathrm{ml}, 250 \mu \mathrm{g} / \mathrm{ml}$ and $125 \mu \mathrm{g} / \mathrm{ml}$.
In the study of membrane stabilization activity, the ethanol extract of $S$. hederaceus at concentration range of 500, 250 and $125 \mu \mathrm{g} / \mathrm{ml}$ protected significantly the erythrocyte membrane against lysis induced by hypotonic solution shown in table 3. Aspirin (500-125 $\mu \mathrm{g} / \mathrm{ml}$ ) also offered a significant (97.02\%, 77.15\%and $61.59 \%)$ protection of the RBC's against the damaging effect induced by hypotonic solution. At a concentration range of $500-125 \mu \mathrm{g} / \mathrm{ml}$, the extract showed $73.19 \%, 49.67 \%$ and $29.15 \%$ inhibition of hypotonic solution-induced haemolysis when compared with the standard.

Table 1. Antipyretic effect of ethanol extract of $S$. hederaceus on Swiss albino mice.

\begin{tabular}{lcccccc}
\hline Groups & Oral dose & \multicolumn{5}{c}{ Rectal temperature in ${ }^{\circ} \mathrm{F}$ at different hours } \\
\cline { 3 - 7 } & & $-24 \mathrm{hr}$ & $0 \mathrm{hr}$ & $1 \mathrm{hr}$ & $2 \mathrm{hr}$ & $3 \mathrm{hr}$ \\
\hline Control (DDW) & $10 \mathrm{mg} / \mathrm{kg}$ & 98.36 & 101.50 & 101.20 & 101.25 & 101.40 \\
Paracetamol & $150 \mathrm{mg} / \mathrm{kg}$ & 98.50 & 101.48 & 97.24 & 98.66 & 98.61 \\
EESH & $500 \mathrm{mg} / \mathrm{kg}$ & 98.58 & 101.53 & 99.86 & 99.20 & 99.06 \\
\hline
\end{tabular}

DDW= Double distilled water; *p $<0.05, \mathrm{EESH}=$ Ethanol extract of $S$. hederaceus

Table 2. Spectrophotometric determination of anti-inflammatory activity of EESH.

\begin{tabular}{lccc}
\hline & \multicolumn{3}{c}{ Mean inhibition of protein denaturation } \\
\hline Test groups & $500 \mu \mathrm{g} / \mathrm{ml}$ & $250 \mu \mathrm{g} / \mathrm{ml}$ & $125 \mu \mathrm{g} / \mathrm{ml}$ \\
\hline Positive control (Aspirin) & 93.12 & 89.65 & 79.31 \\
EESH & 85.17 & 71.72 & 66.55 \\
\hline
\end{tabular}

EESH= Ethanol extract of $S$. hederaceus

Table 3. Spectrophotometric determination of membrane stabilization activity of EESH.

\begin{tabular}{lccc}
\hline & \multicolumn{3}{c}{ Mean inhibition of haemolysis } \\
\hline Test groups & $500 \mu \mathrm{g} / \mathrm{ml}$ & $250 \mu \mathrm{g} / \mathrm{ml}$ & $125 \mu \mathrm{g} / \mathrm{ml}$ \\
\hline Blank(Ethanol) & 0 & 0 & 0 \\
Positive control (Aspirin) & 97.02 & 77.15 & 61.59 \\
EESH & 73.19 & 49.67 & 29.15 \\
\hline
\end{tabular}

$\mathrm{EESH}=$ Ethanol extract of $S$. hederaceus

In DPPH scavenging assay the Ethanol extract showed maximum \% inhibition of $65.5 \%$ at $100 \mu \mathrm{g} / \mathrm{ml}$ while the reference standard ascorbic acid showed \% inhibition of $91.55 \%$ at the same concentration as shown in table 4 . The DPPH radical scavenging activity was increased by increasing the concentration of the sample extract. The extract exhibited considerable DPPH free radical scavenging activity as indicated by their $\mathrm{IC}_{50}$ values which indicate the potency of scavenging activity. Standard ascorbic acid was found to have an $\mathrm{IC}_{50} 52.18 \mu \mathrm{g} / \mathrm{ml}$. Ethanol extract of $S$. hederaceus showed $\mathrm{IC}_{50} 83.93 \mu \mathrm{g} / \mathrm{ml}$. 
Table 4. Radical scavenging activity and $\mathrm{IC}_{50}$ of ethanol extract of $S$. hederaceus by DPPH.

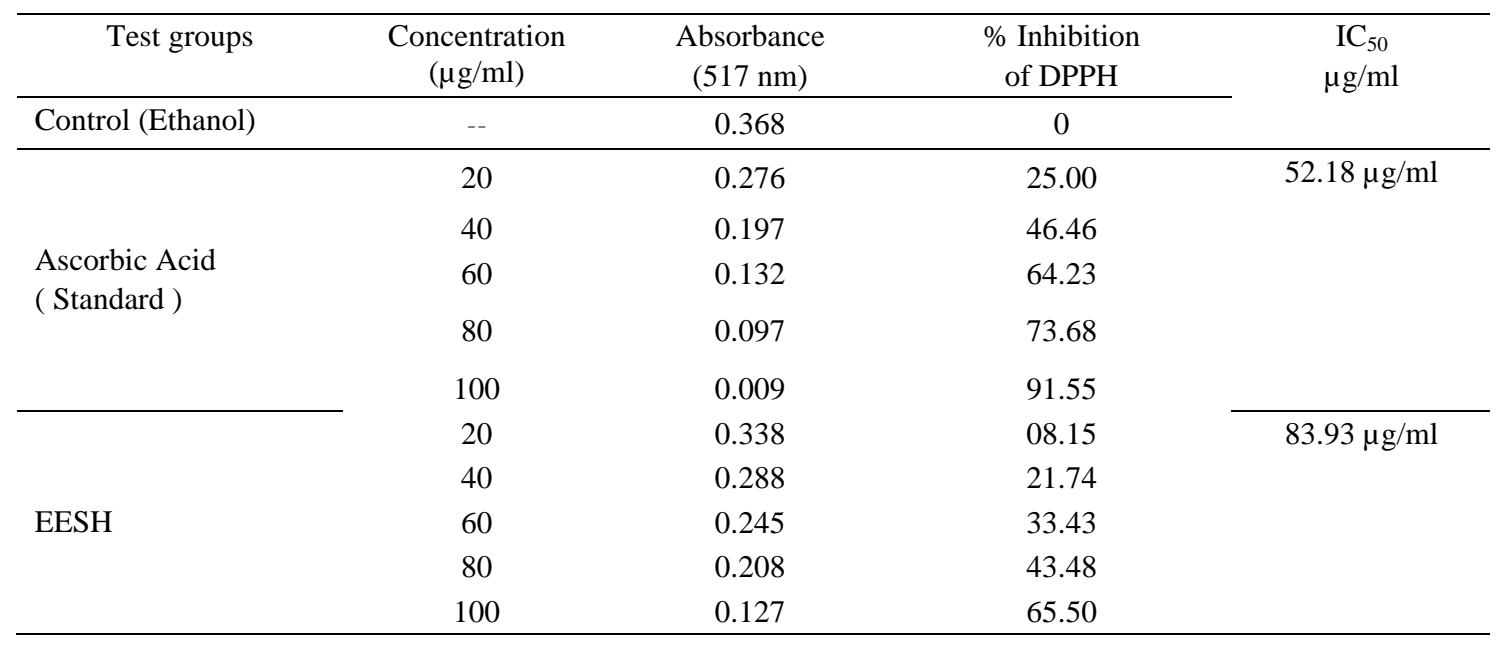

EESH= Ethanol extract of $S$. hederaceus

Results of thrombolytic activity of the plant extracts, control (double distilled water), standard drug (streptokinase), were shown in table 5. In this study, the extractives of $S$. hederaceus showed mild thrombolytic activity in comparison to the standard streptokinase showing $81.54 \%$ clot lysis.The extract showed thrombolytic activity $14.39 \%$ (of clot lysis). At the same time ethanol was treated as negative control which exhibited negligible $8.47 \%$ lysis of clot.

Table 5. Thrombolytic activity of the test groups.

\begin{tabular}{lc}
\hline $\begin{array}{l}\text { Thrombolytic activity of Test } \\
\text { Groups }\end{array}$ & Total lysis \\
\hline Negative control ( ethanol) & $8.47 \pm 0.6$ \\
$\begin{array}{l}\text { Positive control Streptokinase }(100 \\
\mu \mathrm{L})\end{array}$ & $81.57 \pm 3.705$ \\
$\begin{array}{l}\text { Ethanol extracts of } S . \\
\text { hederaceus }(5 \mu \mathrm{g} / \mu \mathrm{L})\end{array}$ & $14.39 \pm 0.80$ \\
\hline
\end{tabular}

Table 6. Inhibition of defecation by ethanol extract of $S$. hederaceus.

\begin{tabular}{lc}
\hline Test groups & $\begin{array}{c}\text { \% of inhibition } \\
\text { defecation }\end{array}$ \\
\hline Negative control & 0.00 \\
\hline Positive control (Loperamide) & $58.87 \pm 0.33$ \\
\hline EESH & $35.30 \pm 0.88$ \\
\hline
\end{tabular}

$\mathrm{EESH}=$ Ethanol extract of $S$. hederaceus
In the castor oil induced diarrheal mice, the ethanol extract of $S$. hederaceus at the dose of $500 \mathrm{mg} / \mathrm{kg}$ showed total $35.30 \%$ inhibition of defecation compared to standard, loperamide ( $3 \mathrm{mg} / \mathrm{kg}$ ) with total $58.87 \%$ inhibition of defecation. (Table 6)

\section{Conclusion}

Antipyretic activity of $S$. hederaceus revealed the significant fever attenuating potential of the plant with significant $(\mathrm{p}<0.05)$ analgesic potential in the extract. The extract of $S$. hederaceus significantly protected the erythrocyte membrane against lysis induced by hypotonic solution and having good anti-inflammatory activity comparable with that of the standard acetyl salicylic acid. It showed significant antioxidant activities in DPPH inhibition assay with mild thrombolytic and moderate anti-diarrheal effect. So, $S$. hederaceus showed statistically significant activities in those tests conducted. The results verify some of the traditional uses of the plant. For instance, further investigation may be carried out to isolate and characterize the active principle of the plant and to elucidate the exact mechanisms of action.

\section{References}

Adams, S.S., Hebborn, P. and Nicholson, J.S. 1998. Some aspects of the pharmacology of ibufenac, a non-steroidal anti-inflammatory agent. J. Pharm. Pharm. 20, 305-312. 
Bhal, B.S. and Bhal, A. 1992. A Text Book of Organic Chemistry, $13^{\text {th }}$ ed. S. Chand \& Company Ltd., pp. 5-6, 11-12, 14.

Brand-Williams, W., Cuvelier, M.E. and Berset, C. 1995. Use of free radical method to evaluate antioxidant activity. Lebensm. Wiss. Technol. 28, 25-30.

De Padua, L.S. and Bunyapraphatsara, R.H.M.J.L. 2003.Plant Resources of South-East Asia No. 12(3): Medicinaland poisonous plants 3. Backhuys Publishers; Leiden, Netherlands.

Evans, W.C. 2002. Trease and Evans' Pharmacognosy. $15^{\text {th }}$ ed., WB Saunders, University of Michigan, p. 64.

Kumari, S., Shukla, G. and Rao, A.S. 2011. The Present Status of Medicinal Plants - Aspects and Prospects, Int. J. Res. Pharm. Biomed. Sci.2, 345-356.

Mahesh, B. and Satish, S. 2008. Antimicrobial activity of some important medicinal plant against plant and human pathogens, World J. Agr. Sci. 4, 839-843.

Omale, J. and Okafor, P.N. 2008. Comparative antioxidant capacity, membrane stabilization, polyphenols composition and cytotoxicity of the leaf and stem of Cissus multistriata. Afr. J. Biotechnol. 7, 3129-3133.
Prasad, S., Kashyap, R.S., Deopujari, J.Y., Purohit, H.J., Taori, G.M. and Daginawala, H.F. 2007. Effect of Fagoniaarabica on in vitro thrombolysis. BMC Complement. Alternat. Med. 7, 36.

Shinde, U.A., Phadke, A.S., Nari, A.M., Mungantiwar, A.A., Dikshit, V.J. and Saraf, M.N. 1999. Membrane stabilization activity-a possible mechanism of action for the anti-inflammatory activity of Cedrus deodarawood oil. Fitoterapia 70, 251-257.

Shoba, F.G. and Thomas, M. 2001. Study of antidiarrhoeal activity of four medicinal plants in castor oil induced diarrhea. J. Ethnopharmacol. 76, 73-76.

Sofowara, A, 1982. Medicinal plants and Traditional Medicine in Africa. Wiley, pp. 6, 10-11, 74, 114.

WHO. Traditional Medicine: Growing Needs and Potential. 2002. WHO Policy Perspectives on Medicines. pp. 1-6.

Zand, J., Spreen, A.N. and LaValle, J.B. 1999. Smart Medicine for Healthier Living. Avery Publishing Group, New York, p. 22. 